\title{
An Analysis of 'Teachers' Attitudes Towards Women School Managers
}

\author{
Ahmet Yildirim $^{1 *}$, Ahmet Üstün ${ }^{2}$, Mustafa Çelikten ${ }^{3}$ \\ ${ }^{1}$ The Bohdan Khmeknytsky National University, Cherkassy, Ukraine \\ ${ }^{2}$ Faculty of Education, Amasya University, Amasya, Turkey \\ ${ }^{3}$ Faculty of Education, Erciyes University, Kayseri, Turkey
}

Keywords:

Women, Manager, Women

Managers, Attitude, Attitudes

Towards Women Managers

\section{Received}

02 January 2021

Received in revised form

23 January 2021

Accepted

26 January 2021

*Correspondence:

aahmetyil25@gmail.com

\begin{abstract}
There has been a lot of research on gender discrimination in school management and factors that prevent women from becoming managers. Examining the literature showed that attitudes contribute to the reasons for the low number of women managers. This research aims to evaluate teacher attitudes towards women school managers. In the 2018-2019 academic year, the research population was composed of teachers in schools/institutions that are woman managers affiliated to the Ministry of National Education in Amasya provinces and districts. The sample size determined by non-selective sampling management was 157 teachers from the Taşova District of Amasya which. Attitude scale towards woman school managers was applied in the study using the method of descriptive screening. The frequency and percentage values of demographics were examined using the SPSS 17 packet program. An Independent t-test was applied to analyse gender, marital status, educational level variables, and one-way variance analysis for the age variable. More than half of the participants in the study described work experimentation with woman managers positively. As a result of the research, significant differences were observed in gender, education status, and age variables. In contrast, no significant differences were observed in terms of marital status variables.
\end{abstract}

CCIKD Publishing

The most important quality that distinguishes man from all other beings and turns him into an individual is his participation in society. In the beginning, it is possible to transform human beings, who were only a biological entity, into a social entity, to have their sentences and values to participate in society by participating in areas such as education, labor, city, and politics. Women play a key role in society (Yavuz, 2015). They always play an important role in developing a healthy, peaceful, and educated new generation. Therefore, women should be given the respect they deserve and not be deprived of their rights (Pinar, 2008). Working and having an income is one of the most fundamental women's rights in today's world. However, motherhood and household 
chores are usually considered a woman's traditional tasks. Working life provides women with various economic freedom, education, social security, and status. Although women contribute to economic life apart from domestic life, they are still expected to fulfill household chores (Ayan, 2000).

Women's higher participation and more active roles in working life and their knowledge, skills, and abilities are now a "strategic obligation" for developing economies. According to Güner (2010), women's participation in the labor force is directly proportional to their educational level. However, women do not seem to occupy more positions in working life despite their increasing education level. This leads to several negative consequences, such as the classification of jobs as male or female jobs, the wage gap between male and female employees, and women's lesser participation in management positions.

Women face many difficulties in working, being promoted, and competing with their colleagues in specific jobs. In Turkey, women mostly prefer working in the public sector due to some advantages such as regular working hours and trust in government institutions (Çelikten, 2005; Çelikten, 2008; Yavuz, 2011). In this respect, teaching is one of the major jobs with a high employment rate in the public sector. Therefore, it is not surprising that women's employment rate in teaching positions is higher compared to other occupational groups. Women's equal employment rate in teaching jobs may result from the fact that teaching is usually associated with motherhood, even in the most conservative societies (Çelikten, 2006; Ministry of National Education, 2005).

The reason women's lower participation in management positions can be attributed to the fact that women are not considered suitable for management and do not demand to be promoted (Yoğun Erçen, 2008). In a similar vein, women and society do not consider women ideal for management positions due to a fear of hindering their traditional roles. Women are usually forced to choose either their career or traditional roles, which they prefer the latter (Ersöz, 1998).

In general, management positions are dominated by men who determine the boundaries as a profession. Until recently, women have not found the opportunity to participate in management and decision-making positions due to men's traditionalist approaches. This can be because of patriarchal social values, self-confidence and mental phenomena, and gender-based segregation (Türktan, 2010). However, in today's world, women started to improve their management skills and skills in other fields and increase their management positions. Although the importance of gender in the distribution of management positions has decreased, the number of women managers is not as high as possible. Besides, women's management and leadership skills that they use in attaining management positions in organizational contexts deserve attention, too (Şahin, 2007).

It is often challenging to find a sufficient number of candidates for management positions. The main criterion for an employee hiring process is professional qualities, not gender. A suitable level of education is considered a decent quality that may help individuals reach a higher socio-economic status. That is why women's career success is directly related to social classes (Çilsal, 2008). Tat (2015) stated that women's common problems in their working lives could be summarized as follows: 1) Childrearing and domestic responsibilities force women to temporarily quit their careers and thus be outdone by other colleagues in the same field; 2) Women's participation rate in education is lower compared to men; 3) Most of the women either quit their jobs when they have a child or are dismissed by their employers; 4) Social and cultural factors that cause problems between families usually prevent women from reaching higher positions in their careers; 5) 
Marriage with a man working in the same professional field is considered a factor that contributes to women's working life (Tat, 2015).

\section{Literature Review}

Toprak, Karakuş, and Chen (2019) reported that gender was a significant and decisive factor in teachers' office duration, management justice, and commitment to the manager. Kutlu and Akbulut (2018) indicated that teachers' attitudes towards women managers were neither negative nor positive nor, to put it differently, neutral. According to Robinson et al. (2017), there was a significant difference between the conditions of a workplace and school managers' gender, career paths, and personal lives. Paoloni and Demartini (2016) found various barriers which women managers encountered on their way to higher management roles. Balgiu (2013) demonstrated that male employees and students did not approach women managers as positively as female employees; those female students trained in management and female employees significantly differed from other groups. Y1ldirım (2017) found out in a study on university lecturers that they maintained a positive attitude towards women managers and, as far as gender variable is concerned, female participants found women managers more positive than male participants in terms of "task role behaviors". Asar and Çelikten (2016) observed that participants' attitudes towards women managers were positive and that female participants' attitudes towards women managers were more positive than male participants. İşeri and Çalık (2019) stated that women managers often experienced problems, particularly with top management and other female teachers. Sart (2014) found that women working in public and private universities were more successful and that women were more successful in private universities by $71 \%$. Connell, Cobia, and Hodge (2015) reported that women teachers were not appointed as managers despite outnumbering men, which could be interpreted as gender discrimination. Cortis and Cassar (2005) conducted a study to analyze factors that prevented women from succeeding in management positions and concluded that male employees displayed a more traditional attitude than women. Gökyer and Çiçek (2016) reported that women managers did not face any negative attitudes in nursery schools, while they were not considered suitable for management positions in high schools. Bakır et al. (2017) observed that women's roles in management positions were not positively approached by their families, social circles, and society. According to Vinkenburg et al. (2011), women leaders displayed more effective leadership traits than men.

Studies focusing on women's negative attitudes in management positions started in the early 1970s and gained momentum in the following years. However, these studies were only carried out in Western countries. One of the first examples is a study on an international distribution company with 280 employees in which women managers displayed a more positive attitude than male counterparts (Terborg et al., 1977).

Aycan et al. (2012) examined the scale of attitudes towards women in his study and applied it to both men and women. As a result, attitudes towards managers were collected in 3 main titles in general, including professional working behaviors, interpersonal relationships, and work ethics. (Aycan et al., 2012). All research on leadership has emphasized the influence of school administrators on the success of the school. A school administrator should be a good model with competence as a leader who correctly reads management processes (Çelikten et al., 2019). McEwan (2018) placed the communication expertise feature at the top of effective school administrators' ten characteristics. He argues that a school administrator interacts with thousands of people in an academic year, communicates in this process, then must have a high level of communication skills. 
For effective management to occur, employees' ability to fully perform their functions depends on healthy mutual communication and interaction. A healthy lack of mutual interaction and communication can lead to disconnection and conflicts between management and teachers. The resulting disconnections and conflicts can lead to inefficiency in educational organizations, which are social organizations. From this point of view, it can be said that interpersonal relations and communication play an important role in educational organizations (Bursalioğlu, 2003). Education managers must act according to professional, ethical principles, laws, and policies in their duties' performance. The leadership role of educational administrators in helping win of the ethical values they have has too many role education administrators and educational policies. The philosophy of this policy is the determination of the values being carried out through the programmes, staff selection, development and evaluation, the rational use of resources, creating a healthy school culture, and the school has an important place for the effective activation (Bursalıoğlu, 2003; Kaya, 1993).

The studies in the existing literature occupy an important position in terms of revealing women managers' attitudes and conditions in management positions. The present study aims to examine teachers' attitudes towards women school managers. In this respect, research sub-questions of the present study can be listed as follows:

1) What are teachers' level of attitudes towards women managers?

2) Is there a significant difference in attitudes towards women managers in terms of gender?

3) Is there a significant difference in attitudes towards women managers in terms of age?

4) Is there a significant difference in attitudes towards women managers in terms of marital status?

5) Is there a significant difference in attitudes towards women managers in terms of level of education?

Women encounter various problems in their working lives, starting from their first day in a job until being promoted to a certain position. In particular, attitudes towards women managers must be fully understood to help women reach and succeed in management positions. It can be stated that attitudes towards a woman manager will influence women's participation in management positions and their management performances once they reach such positions.

The findings of the present study are likely to help related offices and institutions of the Ministry of National Education in terms of women managers, and contribute to other researchers' work in the same field. It is also expected to encourage women to participate more in management positions by exploring the reasons underlying negative attitudes towards women managers in the Turkish education system.

\section{Method}

\section{Model}

A correlational survey model was used in the present study. According to Karasar (2006) and Frankel, Wallen, and Hyun (2011), survey models are usually employed to collect data about personality traits in a group of individuals or their views (competence, opinion, attitude, belief, or knowledge) on a given topic. Even though the survey model does not always yield a reliable cause and effect relationship, it allows the researcher to predict a variable if another variable is known.

\section{Sample}

The population of the present study consists of teachers who work at schools and institutions managed by women managers and affiliated with the Ministry of National Education in Amasya 
province of Turkey during the 2018-2019 school year. The study samples were selected using random sampling, and 148 teachers working at seven different schools managed by a woman manager in the Taşova district of Amasya province participated in the study. The random sampling method facilitates the analysis of a process, as it allows the researcher to select an easily accessible case. This method is usually preferred by researchers when other sampling methods are not available (Büyüköztürk et al., 2012). The frequency and percentage distributions depicting the personal characteristics of the group are presented in Table 1.

Table 1

\begin{tabular}{|c|c|c|c|}
\hline Personel Detail & & $f$ & $\%$ \\
\hline \multirow{2}{*}{ Gender } & Female & 76 & 51.5 \\
\hline & Male & 72 & 48.6 \\
\hline \multirow[t]{3}{*}{ Age } & $21-30$ & 45 & 30.4 \\
\hline & $31-40$ & 75 & 50.7 \\
\hline & 41 and more & 28 & 18.9 \\
\hline \multirow[t]{2}{*}{ Marital Status } & Married & 90 & 60.8 \\
\hline & Single & 58 & 39.2 \\
\hline \multirow[t]{2}{*}{ Educational Level } & Undergraduate & 130 & 87.8 \\
\hline & Graduate & 18 & 12.2 \\
\hline
\end{tabular}

\section{Instrument and Procedures}

The questionnaire used as a data collection tool in the present study consists of two parts. The first part contains a "Personal Information Form" with six items that aim to gather information about participants' demographic variables. The second part is "Attitude towards Women Managers Scale," consisting of twenty-seven items. Developed and tested for reliability and validity by Aycan et al. (2012), the scale was used to measure teachers' attitudes towards women managers. Based on a 7-point Likert scale, responses by each participant range from "Strongly Disagree" to "Strongly Agree". Attitudes in the scale were analyzed in three different factors as Professional Working Behaviors (14 items, Factor 1), Interpersonal Relationships (9 items, Factor 2), and Work Ethics (4 items, Factor 3). A higher score on the scale points to a more positive attitude towards women managers among participants.

\section{Data Analysis}

The frequency and percentage values of participants' demographic features were analyzed. To this aim, a normality test was performed to analyze differences among participants' views, and a normal distribution was observed. An independent t-test was applied for the gender, marital status, educational level, and one-way analysis of variance (One-Way ANOVA) used for the age variable. When a difference was found due to the parametric One-Way ANOVA test, Tukey, which is a multiple comparison test, was used to find the difference. Cronbach Alpha value of "Attitude towards Women Managers Scale" was calculated as .94 in the present study.

\section{Results}

As shown in Table 2, arithmetic mean scores of teachers who participated in the present study for the measurement of attitudes towards women managers in the Attitude towards Women Managers Scale was calculated as $M=3.42$ with a standard deviation of $S D=.89$. As for sub-dimensions of the scale, the same values were calculated as $M=3.29$ and $S D=.79$ for Professional Working 
Behaviors (Factor 1), $M=3.55$ and $S D=.79$ for Interpersonal Relationships (Factor 2), and $M=$ 3.42 and $S D=.73$ for Work Ethics (Factor 3).

Table 2

Average, Standard Deviation and Standard Error Values Scores of Attitude Scale for Female Managers Total Scores

\begin{tabular}{lccccc}
\hline Dimensions & $\mathrm{N}$ & $M$ & $S D$ & $\min$ & $\max$ \\
\hline Professional Working Behaviors & 148 & 3.29 & .89 & 1 & 5 \\
Interpersonal Relationships & 148 & 3.55 & .79 & 2 & 5 \\
Work Ethics & 148 & 3.58 & .79 & 1 & 5 \\
Attitude Scale & 148 & 3.42 & .73 & 1 & 5 \\
\hline
\end{tabular}

As shown in Table 3, t-test results related to participants' total attitude scale and sub-dimension scores on gender variable displayed a statistically significant difference among Factor 1, Factor 2 and attitude scale (Attitude Scale: $t=53, p<.05$; Factor 1: $t=2.74, p<.05$ and Factor 2: $t=4.48$, $p<.05)$. Female teachers had a more positive attitude towards women managers than male teachers. However, no statistically significant differences were observed in Factor $3(p>.05)$.

Table 3

Independent T-test Results According to Gender Variable

\begin{tabular}{|c|c|c|c|c|c|c|c|c|c|}
\hline \multirow{2}{*}{ Dimensions } & \multirow{2}{*}{ Gender } & \multirow{2}{*}{$\mathrm{N}$} & \multirow{2}{*}{$M$} & \multirow{2}{*}{$S D$} & \multirow{2}{*}{$S E$} & \multicolumn{4}{|c|}{ Independent $\mathrm{t}$-test } \\
\hline & & & & & & $t$ & $S E$ & $F$ & $p$ \\
\hline \multirow[b]{2}{*}{ Factor 1} & Female & 76 & 3.64 & .74 & .08 & \multirow[b]{2}{*}{5.30} & \multirow[b]{2}{*}{.13} & \multirow{2}{*}{4.17} & \multirow{2}{*}{.00} \\
\hline & Male & 72 & 2.92 & .90 & .10 & & & & \\
\hline \multirow[b]{2}{*}{ Factor 2} & Female & 76 & 3.72 & .86 & .09 & \multirow[b]{2}{*}{2.74} & \multirow[b]{2}{*}{.12} & \multirow[b]{2}{*}{3.05} & \multirow[b]{2}{*}{.00} \\
\hline & Male & 72 & 3.37 & .68 & .08 & & & & \\
\hline \multirow{2}{*}{ Factor 3} & Female & 76 & 3.64 & .84 & .09 & \multirow[b]{2}{*}{0.97} & \multirow[b]{2}{*}{.13} & \multirow[b]{2}{*}{0.66} & \multirow[b]{2}{*}{.33} \\
\hline & Male & 72 & 3.52 & .73 & .08 & & & & \\
\hline \multirow{2}{*}{ Attitude Scale } & Female & 76 & 3.66 & .69 & .07 & \multirow{2}{*}{4.48} & \multirow{2}{*}{.11} & \multirow{2}{*}{0.00} & \multirow{2}{*}{.00} \\
\hline & Male & 72 & 3.16 & .68 & .08 & & & & \\
\hline
\end{tabular}

As indicated in Table 4, the one-way ANOVA test results obtained from participants' total attitude scale and sub-dimension scores on the age variable $(p<.05)$ revealed a statistically significant difference in Factor 1, Factor 2, and an attitude scale.

Table 4

One-way ANOVA Test Results According to Age Variable

\begin{tabular}{|c|c|c|c|c|c|c|c|c|c|c|}
\hline Dimensions & Age & $\mathrm{N}$ & $M$ & $S D$ & Groups & $S S$ & $d f$ & $M S$ & $F$ & $p$ \\
\hline \multirow{3}{*}{ Factor 1} & $21-30$ & 45 & 3.49 & .85 & Between & 5.32 & 2 & 2.66 & \multirow{4}{*}{3.40} & \multirow{4}{*}{.03} \\
\hline & $31-40$ & 75 & 3.30 & .93 & Within & 113.60 & 145 & 0.78 & & \\
\hline & 41- and + & 28 & 2.93 & .79 & Total & 118.93 & 147 & & & \\
\hline \multirow{5}{*}{ Factor 2} & Total & 148 & 3.29 & .89 & & & & & & \\
\hline & $21-30$ & 45 & 3.72 & .77 & Between & 5.33 & 2 & 2.66 & \multirow{4}{*}{4.38} & \multirow{4}{*}{.01} \\
\hline & $31-40$ & 75 & 3.58 & .89 & Within & 88.24 & 145 & 0.69 & & \\
\hline & 41- and + & 28 & 3.17 & .33 & Total & 93.57 & 147 & & & \\
\hline & Total & 148 & 3.55 & .79 & & & & & & \\
\hline \multirow{4}{*}{ Factor 3} & $21-30$ & 45 & 3.62 & .79 & Between & 2.46 & 2 & 1.23 & \multirow{4}{*}{1.98} & \multirow{4}{*}{.14} \\
\hline & $31-40$ & 75 & 3.66 & .87 & Within & 90.12 & 145 & 0.62 & & \\
\hline & 41- and + & 28 & 3.32 & .45 & Total & 92.58 & 147 & & & \\
\hline & Total & 148 & 3.58 & .79 & & & & & & \\
\hline \multirow{4}{*}{$\begin{array}{l}\text { Attitude } \\
\text { Scale }\end{array}$} & $21-30$ & 45 & 3.58 & .73 & Between & 4.58 & 2 & 2.59 & \multirow{4}{*}{4.47} & \multirow{4}{*}{.01} \\
\hline & $31-40$ & 75 & 3.45 & .78 & Within & 74.28 & 145 & 0.51 & & \\
\hline & 41- and + & 28 & 3.07 & .42 & Total & 78.86 & 147 & & & \\
\hline & Total & 148 & 3.42 & .73 & & & & & & \\
\hline
\end{tabular}

Tukey test was performed to reveal the difference between groups, as presented in Table 5 . Based on the Tukey test results related to participants' total attitude scale, Factor 1 and 2 scores in terms of age, a statistically significant difference was observed in favor of 21-30 between 21-30 and 41 and over age groups. Thus, it can be argued that teachers who have recently started their 
teaching career display a more positive attitude towards women managers compared to their elder colleagues.

Table 5

Tukey Test Results According to Age Variable

\begin{tabular}{|c|c|c|c|c|c|}
\hline Dimensions & Age (I) & Age (II) & $M$ & $S E$ & $p$ \\
\hline \multirow{4}{*}{ Factor 1} & $21-30$ & $\begin{array}{c}31-40 \\
41 \text { and }+\end{array}$ & $\begin{array}{l}.18 \\
.55\end{array}$ & $\begin{array}{l}.16 \\
.21\end{array}$ & $\begin{array}{l}.52 \\
.02\end{array}$ \\
\hline & $31-40$ & $\begin{array}{c}21-30 \\
41 \text { and }+\end{array}$ & $\begin{array}{l}-.18 \\
.37\end{array}$ & $\begin{array}{l}.16 \\
.19\end{array}$ & $\begin{array}{l}.52 \\
14\end{array}$ \\
\hline & \multirow{2}{*}{40 and + } & $21-30$ & -.55 & .21 & .02 \\
\hline & & $31-40$ & -.37 & .19 & .14 \\
\hline \multirow{6}{*}{ Factor 2} & \multirow{2}{*}{$21-30$} & $31-40$ & .13 & .14 & .63 \\
\hline & & 41 and + & .54 & .18 & .01 \\
\hline & \multirow{2}{*}{$31-40$} & $21-30$ & -.13 & .14 & .63 \\
\hline & & 41 and + & .41 & .17 & .05 \\
\hline & \multirow{2}{*}{40 and +} & $21-30$ & -.54 & .18 & .01 \\
\hline & & $31-40$ & -.41 & .17 & .05 \\
\hline \multirow{6}{*}{ Attitude Scale } & \multirow{2}{*}{$21-30$} & $31-40$ & .12 & .13 & .63 \\
\hline & & 41 and + & .50 & .17 & .01 \\
\hline & \multirow{2}{*}{$31-40$} & $21-30$ & -.12 & .13 & .63 \\
\hline & & 41 and + & .38 & .15 & .05 \\
\hline & \multirow{2}{*}{40 and +} & $21-30$ & -.50 & .17 & .01 \\
\hline & & $31-40$ & -.38 & .15 & .05 \\
\hline
\end{tabular}

As demonstrated in Table 6, t-test results related to participants' total attitude scale and subdimension scores on marital status $(\mathrm{p}>.05)$ indicated no statistically significant difference in any sub-dimensions.

Table 6

Independent T-test Results According to Marital Status Variable

\begin{tabular}{|c|c|c|c|c|c|c|c|c|c|}
\hline \multirow{2}{*}{ Dimensions } & \multirow{2}{*}{ Marial Status } & \multirow{2}{*}{$\mathrm{N}$} & \multirow{2}{*}{$M$} & \multirow{2}{*}{$S D$} & \multirow{2}{*}{$S E$} & \multicolumn{4}{|c|}{ Independent $\mathrm{T}$ Test } \\
\hline & & & & & & $t$ & $S E$ & $F$ & $p$ \\
\hline \multirow[b]{2}{*}{ Factor 1} & Married & 90 & 3.18 & .90 & .09 & \multirow[b]{2}{*}{-1.83} & \multirow[b]{2}{*}{.15} & \multirow[b]{2}{*}{0.02} & \multirow[b]{2}{*}{.06} \\
\hline & Single & 58 & 3.46 & .87 & .11 & & & & \\
\hline \multirow[b]{2}{*}{ Factor 2} & Married & 90 & 3.50 & .66 & .06 & \multirow[b]{2}{*}{-0.76} & \multirow[b]{2}{*}{.14} & \multirow[b]{2}{*}{14.91} & \multirow[b]{2}{*}{.44} \\
\hline & Single & 58 & 3.62 & .97 & .12 & & & & \\
\hline \multirow{2}{*}{ Factor 3} & Married & 90 & 3.62 & .72 & .07 & \multirow{2}{*}{0.68} & \multirow[b]{2}{*}{.13} & \multirow{2}{*}{1.34} & \multirow[b]{2}{*}{.49} \\
\hline & Single & 58 & 3.53 & .89 & .11 & & & & \\
\hline \multirow{2}{*}{$\begin{array}{l}\text { Attitude } \\
\text { Scale }\end{array}$} & Married & 90 & 3.35 & .67 & .07 & \multirow{2}{*}{-1.32} & \multirow{2}{*}{.12} & \multirow{2}{*}{5.82} & \multirow{2}{*}{.18} \\
\hline & Single & 58 & 3.52 & .81 & .10 & & & & \\
\hline
\end{tabular}

Table 7 shows t-test results related to participants' total attitude scale and sub-dimension scores on education level. There was a statistically significant difference in the attitude scale and Factor 1. Thus, it can be concluded that teachers who have an undergraduate degree developed a more positive attitude towards women managers than teachers who have a graduate degree. 
Table 7

Independent T-test Results According to Educational Level Variable

\begin{tabular}{|c|c|c|c|c|c|c|c|c|c|}
\hline \multirow{2}{*}{ Dimensions } & \multirow{2}{*}{ Educational Level } & \multirow{2}{*}{$\mathrm{N}$} & \multirow{2}{*}{$M$} & \multirow{2}{*}{$S D$} & \multirow{2}{*}{$S E$} & \multicolumn{4}{|c|}{ Independent T Test } \\
\hline & & & & & & $t$ & $S E$ & $F$ & $p$ \\
\hline \multirow{2}{*}{ Factor 1} & Undergraduate & 130 & 3.38 & 0.84 & .07 & \multirow{2}{*}{3.40} & \multirow[b]{2}{*}{.21} & \multirow[b]{2}{*}{1.19} & \multirow{2}{*}{.00} \\
\hline & Graduate & 18 & 2.64 & 1.01 & .23 & & & & \\
\hline \multirow[b]{2}{*}{ Factor 2} & Undergraduate & 130 & 3.58 & 0.78 & .06 & \multirow[b]{2}{*}{1.28} & \multirow[b]{2}{*}{.20} & \multirow[b]{2}{*}{0.57} & \multirow[b]{2}{*}{.20} \\
\hline & Graduate & 18 & 3.32 & 0.86 & .20 & & & & \\
\hline \multirow{2}{*}{ Factor 3} & Undergraduate & 130 & 3.62 & 0.76 & .06 & \multirow[b]{2}{*}{1.52} & \multirow[b]{2}{*}{.19} & \multirow[b]{2}{*}{2.64} & \multirow[b]{2}{*}{.12} \\
\hline & Graduate & 18 & 3.31 & 0.96 & .22 & & & & \\
\hline \multirow[b]{2}{*}{ Attitude Scale } & Undergraduate & 130 & 3.48 & 0.69 & .06 & \multirow[b]{2}{*}{2.78} & \multirow[b]{2}{*}{.18} & \multirow[b]{2}{*}{2.21} & \multirow[b]{2}{*}{.00} \\
\hline & Graduate & 18 & 2.98 & 0.87 & .20 & & & & \\
\hline
\end{tabular}

\section{Discussion}

The present study mainly focuses on the assessment of teachers' attitudes towards women school managers. Attitudes towards women managers in the scale were divided into three factors: professional working behaviors, interpersonal relationships, and work ethics.

The result of the study indicated that $61 \%$ of the participants display a positive attitude towards women managers. This result is similar to the studies of Chullen et al. (2017), Yildirım (2017), Asar and Çelikten (2016), Balcı and İnan (2016), Sart (2014), Vinkenburg et al. (2011) and Galanaki et al. (2009). On the other hand, Litwin et al. (2019), Bakır et al. (2017), Nergiz and Yemen (2011), and Güney et al. (2006) reported in their respective studies that participants maintained a negative attitude towards women managers. Finally, Kutlu and Akbulut (2018) found out in their study that attitudes towards women managers were neither positive nor negative, thus being neutral. Despite the fact that most teachers develop a positive attitude towards women managers in the school environment, some teachers maintain a relatively negative attitude towards women managers, which may result from their familiarity with male managers in their personal past.

The findings of the present study demonstrated that statistically significant differences were observed in the total scale scores as well as the sub-dimensions of professional working behaviors and interpersonal relationships in terms of gender variable. Thus, it was observed that female teachers display a more positive attitude towards women managers than male teachers and think that women managers had a sufficient level of professional working behaviors and interpersonal relationships. This finding supports Özkan (2006), Mostafa (2005), Sevim (2006), Çelik, (2008), Çitak (2008), Negiz and Yemen (2011), Uçan (2012), Asar (2014) and Tat (2015), Asar and Çelikten (2016), and Balcı and İnan (2016). However, according to Yıldırım (2017), when it comes to gender variable, female participants found women managers more positive in the sub-dimension of "task role behaviors". Similarly, Connell, Cobia, and Hodge (2015) report gender discrimination in organizational structures. Litwin, Ngan, and Atembe (2019) analyzed attitudes towards women managers in terms of gender variable and concluded that attitudes towards women managers heavily influenced gender-related policies and that a high-profile sector was likely to need talent management more rather than gender equality policies. Galanaki, Papalexandris, and Halikias (2009) did not report any statistically significant differences in gender variable. In a study on attitudes towards women managers, Aycan et al. (2012) reported a negative correlation with traditionalist approaches to gender roles. Besides, it can also be argued that female teachers' more positive attitude towards women managers compared to male teachers stem from women's solidarity. Men and women in executive positions will inevitably have different attitudes towards 
them due to their diverse interests and biological structures. Koroncu Özbilen (2017) concluded that academicians think solidarity among women is because they have a shared history and share many feelings. Although they compete because their academic life share is relatively less than male academicians, passing through the same difficulties sometimes brings them closer. A woman teacher may want the principal of the school to be a woman for solidarity.

The present study found no statistically significant differences in the total scale scores and the sub-dimensions of professional working behaviors and interpersonal relationships in terms of age variable. As a result, it can be stated that teachers aged between 21 and 30 maintain a more positive attitude towards women managers and think that these managers had a sufficient level of professional working behaviors and interpersonal relationships, which is supported by Çelik, (2008) and Mostafa (2005). In a study focusing on teachers', managers' and inspectors' attitudes towards women managers, Çelik (2008) reported that participants' total scores of scale and subdimensions displayed differences in age variables. Thus, it can be argued that younger generations show a more liberal identity than under 30 and 31-40 age groups and are more satisfied with working under women managers. In contrast, their attitude scores gradually decrease in reverse proportion to their age. However, Uçan (2012) and Asar (2014) indicated that the age variable did not affect participants' attitudes towards women managers.

In the present study, a statistically significant difference was observed in the total scale scores and the sub-dimension of professional working behaviors regarding the level of education variable. It was found out that teachers with an undergraduate degree displayed a more positive attitude towards women managers than teachers with a graduate degree. This finding differs from Kazgan (1979), Demirel et al. (1999), Kuzgun and Sevim (2004), Çitak (2008), Turkis Statistical Institute, 2011, and Çelik (2008), who reported that level of education was directly proportional to a more positive attitude towards working women. For instance, Çelik (2008) observed a positive attitude towards women managers among participants with a master's degree and stated that teachers' attitudes towards women managers became more positive as their level of education increased. Additionally, in terms of the level of education, the most positive attitude towards women managers was displayed by participants with a master's degree. Therefore, it can be suggested that an increasing level of education in society will bring about more women managers in organizational structures.

\section{Conclusion and Suggestions}

In the study on the evaluation of teacher attitude towards women managers scale, it is seen that teachers have a positive attitude towards women managers. According to the study results, there is differentiation according to the gender variable, and women teachers have a more positive attitude towards female directors than men teachers. Significant differences were observed mainly in the sub-dimensions of professional working behaviors and interpersonal relationships. According to the results of the study, teachers who are at the beginning of their profession show more positive attitudes towards women managers. In the present study, a statistically significant difference was observed in the total scale scores and the sub-dimension of professional working behaviors regarding the level of education variable. Teachers with an undergraduate degree displayed a more positive attitude towards women managers than teachers with a graduate degree. No statistically significant differences were observed among participants' attitudes towards women managers regarding the marital status variable. 
The sample of the present study may be expanded or changed for future studies. Besides, qualitative and/or mixed research methods may be used to obtain different data. The data obtained from the present research that focuses on women managers' attitudes may help eliminate prejudice against women and any other doubts on this issue. Further studies may be carried out to reveal individuals' views on women managers outside the business world. The present study only analyzed attitudes towards women managers in educational institutions. Further research on male managers in educational contexts may also reveal attitudes towards these managers.

\section{References}

Asar, R. (2014). Evaluation of attitudes towards women managers in educational institutions (Unpublished master's thesis). Erciyes University Institute of Educational Sciences, Kayseri.

Asar, R., \& Çelikten, M. (2016). Evaluation of the attitudes towards women managers working at educational institutions. OPUSInternational Journal of Community Research, 6, 8-19.

Ayan, F. (2000). Principals of female teachers and teachers' views (Unpublished master's thesis). Onsekiz Mart University. Retrieved from https://tez.yok.gov.tr/UlusalTezMerkezi/tezSorguSonucYeni.jsp (Dissertation No. 99651)

Aycan, Z., Bayazit, M., Berkman, Y., \& Boratav, H. B. (2012). Attitudes towards women managers: Development and validation of a new measure with Turkish samples. European Journal of Work and Organizational Psychology, 21, 426-455.

Bakır, A. A., Uğurlu, C. T., Köybaşı, F., \& Özyazıcı, K. (2017). A qualitative research on female school administrators. Current Research in Education, 3, 1-14.

Balc1, N., \& İnan, İ. (2016). Attitudes towards female managers in educational institutions. (Unpublished master's thesis). Çağ University Institute of Social Sciences, Mersin.

Balgiu, B. A. (2013). Perception of women as managers. Attitude difference between employees and non-employees. ProcedureSocial and Behavioral Sciences, 78, 330-334.

Bursalığlu, Z. (2003). Theory and practice in educational administration (7 $7^{\text {th }}$ ed.). Ankara: Pegem A Publishing.

Büyüköztürk, Ş., Kılıç Çakmak, E., Akgün, Ö. E., Karadeniz, Ş., \& Demirel, F. (2012). Scientific research methods. Ankara: Pegem A Publishing.

Chullen, C. L., Adeyemi-Bello, T., \& Vermeulen, E. (2017). A comparative analysis of attitudes towards women as managers in the US and Netherlands. Journal of Leadership, Accountability and Ethics, 14, $24-42$.

Connell, P. H., Cobia, F. J., \& Hodge, P. H. (2015). Women's journey to the school superintendency. Alabama Journal of Educational Leadership, 2, 37-63.

Cortis, R., \& Cassar, V. (2005). Perceptions of and about women as managers: Investigating job involvement, self-esteem and attitudes. Women in Management Review, 20, 149-164.

Çelik, B. (2008). The relationship between attitudes and thinking styles towards women managers (Unpublished master's thesis). Gaziosmanpaşa University Institute of Social Sciences, Tokat.

Çelikten, M. (2005). The women principals chair in Turkey. The Journal of American Academy of Busines, 6, 85-94.

Çelikten, M. (2006). Culture and teacher metaphors. Journal of Social Sciences Institute, 21, 269-283.

Çelikten, M. (2008). Quality of life in Turkish university students and its relationship to levels of state-trait anxiety. Social Behavior and Personality, 36, 417-424.

Çelikten, Y., Yıldırım, A., Çelikten, M., \& Ayyıldız, K. (2019). Professional school management and the woman factor. Journal of İnönü University Educational Sciences Institute, 6, 123-143.

Çilsal, Z. (2008). Differences and similarities in terms of gender in school management behaviors (Unpublished master's thesis). Erciyes University Institute of Social Sciences, Kayseri.

Çitak, A. (2008). Attitude towards women's work: A comparison by gender, gender role and socioeconomic level (Unpublished master's thesis). Ankara University Institute of Social Sciences, Ankara.

Demirel, A., Kayaalp Bilgin, Z., \& Kocaman, M. (1999). Urban women as a workforce ready to work and their exchange. Ankara: Publications of the Directorate General of the Status and Problems of the Prime Ministry. 
Ersöz, A. (1998). Expectations of women working as administrators in public administration regarding traditional and working women roles. In O. Çitci (Ed.), Women at the end of the 20th century and the future (pp. 255-264). Ankara: TODAIE Publications.

Frankel, R. J., Wallen, E. N., \& Hyun, H. H. (2011). How to design and evaluate research in education (8 ${ }^{\text {th }}$ ed.). New York: McGraw-Hill.

Galanaki, E., Papalexandris, N., \& Halikias, J. (2009). Revisiting leadership styles and attitudes towards women as managers in Greece. Gender in Management: An International Journal, 24, 1-24.

Gökyer, N., \& Çiçek, F. (2016). Opinions of teachers working with women managers on the competencies of women managers. Journal of Kirsehir Education Faculty, 17, 747-766.

Güner, M. T. A. (2010). women's labor force and women's labor force participation: Women's employment in crisis periods (Unpublished master's thesis). Gazi University Institute of Social Sciences, Ankara.

Güney, S., Gohar, R., Akınc1, S. K., \& Akınc1, M. M. (2006). Attitudes toward women managers in Turkey and Pakistan. Journal of International Women's Studies, 8, 194-211.

İşeri, E. T., \& Çalık, T. (2019). Institutional career barriers faced by female school administrators and ways to overcome them. Journal of Human and Social Sciences Researches, 8, 1470-1503.

Karasar, N. (2006). Scientific research method (16 ${ }^{\text {th }}$ ed.). Ankara: Nobel Publications.

Kaya, Y. K. (1993). Management: Theory and practice in Turkey. Ankara: Science Books Stationery Limited Company.

Kazgan, G. (1979). Women's participation in the workforce, occupational distribution, educational level, and socioeconomic status within the Turkish economy. In N. Abadan-Unat (Ed.), Women in Turkish society (pp. 271-286). Istanbul: Ekin Publications

Koroncu Özbilen, D. (2017). Psychological harassment and organizational silence-voiceover perceptions of female academicians (Unpublished doctoral dissertation). Marmara University Institute of Social Sciences, İstanbul.

Kutlu, G., \& Akbulut, Y. (2018). Attitudes towards female managers in hospitals: Case study of Turkey. International Journal of Healthcare Management, 13, 212-220.

Kuzgun, Y., \& Sevim, S. A. (2004). The relationship between attitude towards women's work and religious orientation. Ankara University Faculty of Educational Sciences Journal, 37, 14-27.

Litwin, A., Ngan, H. F. B., \& Atembe, R. (2019). Attitudes towards female managers in Austrian and Macau tourism industry. Journal of Hospitality and Tourism Management, 39, 1-8.

McEwan, E. K. (2018). 10 characteristics of effective school administrators. USA: Corwin Press

Ministry of National Education (2005). National education numerical data 2004-2005. Ankara: Ministry of National Education Department of Publications.

Mostafa, M. M. (2005). Attitudes towards women managers in the United Arab Emirates. Journal of Managerial Psychology, 20, $522-540$.

Negiz, N., \& Yemen, A. (2011). Women managers in public organizations: Women problematic in management in terms of managers and employees. Süleyman Demirel University Faculty of Arts and Sciences Journal of Social Sciences, 24, 195-214.

Özkan, D. (2006). The relationship between attribution related to acquisition of managerial position by women, attitudes toward women managers, sexism and sex differences (Unpublished master's thesis). Middle East Technical University Institute of Social Sciences, Ankara.

Paoloni, P., \& Demartini, P. (2016). Women in management: Perspectives on a decade of research (2005-2015). Palgrave Communications, 2, 1-7.

Pinar, F. (2008). Problems of women working in Barbara Frischmuth and cultural relations. (Unpublished master's thesis). Yüzüncü Yıl University). Retrieved from https://tez.yok.gov.tr/UlusalTezMerkezi/tezSorguSonucYeni.jsp

Robinson, K., Shakeshaft, C., Grogan, M., \& Newcomb, W. S. (2017). Necessary but not sufficient: The continuing inequality between men and women in educational leadership, findings from the American Association of School Administrators MidDecade Survey. In Frontiers in Education, 2, 1-12.

Sart, G. (2014). Woman leadership in higher education institution of Turkey. Paper presented at $5^{\text {th. }}$ International Conference on Education \& Educational Psychology.

Sevim, S. A. (2006). Religious tendency and gender roles: Determinants of attitudes towards women's job roles. Social Behavior and Personality: An International Journal, 34, 77-86.

Şahin, G. (2007). The place and career problems of women managers in educational organizations (Unpublished master's thesis). Yeditepe University Institute of Social Sciences, Istanbul.

Tat, F. (2015). Opinions of teachers and managers working with women managers on the competencies of women managers (Unpublished master's thesis). Firat University Institute of Educational Sciences, Elazı $\breve{g}$. 
Terborg, J. R., Peters, L. H., Ilgen, D. R., \& Smith, F. (1977). Organizational and personal correlates of attitudes toward women as managers. Academy of Management Journal, 20, 89-100.

Toprak, M., Karakus, M., \& Chen, J. (2019). Teachers' attitudes towards their school managers and their intent to leave: A gendermoderated model. Current Psychology, 1-15. http://doi.org/10.1007/s12144-019-00537-x

Turkey Statistical Institute. (2011). Definitions and concepts. Retrieved from http://www.tuik.gov.tr /MicroVeri/Hia_2011/turkce/metaveri/tanim/index.html

Türktan, G. (2010). Woman in management. Paper presented at $19^{\text {th }}$ Quality Congress, İstanbul.

Uçan, M. (2012). The relationship between the attitudes of teachers working in primary schools towards female administrators and the leadership styles perceived in female administrators: Istanbul province, Kadlköy district (Unpublished master's thesis). Yedi Tepe University Institute of Social Sciences, İstanbul.

Vinkenburg, C. J., Van Engen, M. L., Eagly, A. H., \& Johannesen-Schmidt, M. C. (2011). Investigating stereotypical beliefs about leadership styles: Is transformational leadership a way to promote women? Quarterly Leadership, 22, 10-21.

Yavuz, N. (2011). Role conflict of female executives working in the education sector (Kocaeli province sample) (Unpublished master's thesis). Erciyes University Institute of Educational Sciences, Kayseri.

Yavuz, Ö. (2015). The role of local governments in women's participation in social life (Unpublished master's thesis). Istanbul Gelişim University Institute of Social Sciences, İstanbul.

Yildırım, N. (2017). Attitudes of faculty members working at universities towards female managers. Turkish Studies, 12, 588601.

Yoğun Erçen, A. E. (2008). Women's glass ceiling strategies: A study in large-scale Turkish businesses (Unpublished doctoral dissertation). Çukurova University Institute of Social Sciences, Adana. 